\title{
The Influence of Social Demographic Factor on Individual Decision of Cross-border Migration between Timor Leste and Indonesia
}

\author{
Petrus Kase \\ Department of Public Administration \\ University of Nusa Cendana \\ Kupang, Indonesia \\ kasepetrus@yahoo.co.id
}

\begin{abstract}
Recently cross-border migration of people from Timor Leste to Indonesia cannot be dammed, but data regarding the influence of social demographic factor on this phenomenon have not been adequately described yet. This research examines the influence of social demographic factors on individual decision to cross-border migration from Timor Leste to Indonesia. It used quantitative method to analyse causal correlation between social demographic factors and individual decision to cross-border migration from Timor Leste to Indonesia. The research respondents amounted to $\mathbf{1 6 5}$ including Timor Leste migrants, and immigration and security official in the cross-border areas of Timor Leste and Indonesia. Data obtained from questionnaires then were analysed through descriptive statistic, Pearson correlation and simple linear regression techniques. This research found that social demographic factors including age, sex, marital status, religion, education, job, residency status, and social relation have no correlation and influence on individual decision to cross-border migration from Timor Leste to Indonesia. Cross-border migration of people from Timor Leste to Indonesia, especially in West Timor is mostly because of geographical closeness, social/family visit, study continuation and trade.
\end{abstract}

Key words : cross-border migration, social demographic factors, individual decision

\section{INTRODUCTION}

Recently, cross border migration of people from Timor Leste to Indonesia cannot be dammed. In line with the rapid flow of goods and capital occurring through global trade between the two countries, cross-border migration from Timor Leste to Indonesia also increases significantly. In fact, Indonesia especially West Timor territory has become the main place of migration destination. Within a day, movement of people from Timor Leste to Indonesia through border gate Mota'ain and Batugede reaches more than 100 people (Mota'ain Immigration Office, 2015).

Migration flow of people from Timor Leste to Indonesia increases significantly in its social cultural, economic and demographic scale and complexity. In fact, it involves a large number of men and women in various age, religion, marital status, work status, and education level with various aims such as family visit, study continuation, and goods purchasing. The migration flow is also assumed to have significant effects on safety assurance, law violence, social conflict, life need assurance, residential status, work status, education, health and so on if Indonesian government cannot manage it and if intervention programs of Indonesian government cannot be formulated and implemented successfully. Therefore, this research is done to obtain accurate data and information regarding the main issues of migration flow of people from Timor Leste to Indonesia so that Indonesian government can formulate and implement effective strategic policies to manage the migration flow. In particular, this research aims to describe and analyze the influence of social demographic factors on individual decision to migrate across the border line from Timor Leste to Indonesia.

\section{THEORETICAL REVIEW}

\section{A. The concept of migration, mobile population and migrant}

There are several concepts related to migration such as mobilization, mobile population and migrant. Mobilization means movement of people from one place to another. It involves people who possibly or impossibly move to be permanent residence and time period of its movement is not determined obviously. Migration involves movement from one country or place to another country or place. It can not only be categorized as internal migration that is movement of population from one place to another within a country but also international migration that is movement of population from one country to another. Migrant is person who migrates often with the reason for work. Migrant workers with their families involve workers in the border area of neighbor country, return every day or at least once a week to their country, for example, seasonal worker, seaman, mobile worker, specific migrant worker, autonomous worker (UN Information Service, 2003; Santos and Munez, 2003). Another concept related to migrant is mobile population involving seaman, sex commercial workers, domestic helper, long distance truck driver, and illegal or irregular migrant. Within their trip from 
their original place to destination place, they often cross over a complex system of movement. They are part of movement relevant to population change caused by factors such as work loss, family duty and pension (Skeldon, 2000; Santos and Munez, 2003).

\section{B. Individual migrant characteristics}

Every individual migrant has his/her own characteristic both demographic, social and economic. Several studies conducted for example by Tran (2012), Martinez (2014) and Wilson et. al (2014) explains demographic, social and economic characteristics. According to Tran (2012) demographic characteristic of individual Vietnamese migrant in Brisbane, Australia involves variables such as gender, parents' age, duration of residency in Australia, marital status, number of children, age of children, income earning, work status, and education level. Moreover, according to Martinez (2014), demographic characteristic of individual migrant involves variables such as age, education, marital status, family size, house ownership, health insurance, and receiver of government aid, while according to Wilson et. al (2014) demographic factor of individual migrant involves variables such as age, gender, education and marital status. So far, economic factors involves house ownership, number of household utilities (pure water, power/electricity, sewage, refrigerator, stove, washing machine, sewing machine, radio, television, stereotape, telephone, internet access, computer, cecular phone), vehicle ownership, and business ownership (shop, restaurant, bar, farm, livestock and so on).

\section{Migration determinant factors}

Studies regarding migration can be categorized in two areas including migration determinants and migration impacts on receiver community, family, and migrant community in their place of origin. Literature on migration determinants tends to analyze decision to migrate as an individual rational decision mainly motivated by a hope to procure netto income in destination region. With this neoclassic model of migration, migrants always think of income and detriment differences. Therefore, individuals decide to migrate if netto income that will be obtained is positive. However, this approach remains focus on the impact of job market and salary procurement as main determinant factors of migration. This approach considers that social, economic and demographic characteristic of individual and his/her family related to income potential determine cost benefit calculation of migration (Martinez, 2014).

However, consistent with the majority of literature about migration, Martinez (2014) research on "Beyond Networks: Health, Crime, and Migration in Mexico" places variables such as social, economic and demographic characteristic, access to migration network, individual health status, criminal issues, perspective on permanent residence as main issues that determine migration decision. According to this research, women who are diagnosed with heart problem tend to migrate, while men who are diagnosed to have hypertension tend to migrate to United States. In terms of crime and violence, woman who lives by herself and becomes a victim of robbery or a kind of more serious crime prefers to migrate to other cities in Mexico rather than to United States. Individual thought about life condition in the past and in the future, statistically have no correlation to domestic and international migration for men and women. However, according to Martinez (2014), access to international migration network continuously correlates to individual decision to migrate. Migration network is very important because network can help directly the availability of foodstuff, housing, transportation and information regarding job opportunity and safety when cross the border. The consequences are that international migration network can decrease the costs, but enhance the possibility of success for all migrants, especially those who have low income.

Darwin et. al (2003) also states that migration flow from Indonesia to Malaysia generally can be explained by using factors such as strong push factors including big economic pressure, scarcity of work opportunities, and high level of poverty, in Indonesia, while strong pull factors include success story of those who return from Malaysia specifically about Ringgits taken home and high salary in destination country. However, economic factors are not the only push and pull factors because there are many other factors such as geography, history, social, culture and politics. Geographic nearness along Sumatera and Kalimantan, and the very close social and cultural connection especially Dayak and Malaysia in border area of Kalimantan in fact also enable migration of people from Indonesia to Malaysia. Darwin et. al (2003) also states that migration theory assumes that : (1) migrant is free individual who has autonomy to make his/her own decision to migrate; (2) migrants are rational men who make decision based on cost benefit judgment and judgment of what is best for them; and (3) decision to migrate is made by autonomous individuals as the result of their rational judgments.

\section{RESEARCHMETHOD}

This research is a causal correlation research using quantitative data collection method to measure or test causal relationship between social demographic factors (independent variable) and individual decision to migrate from Timor Leste to Indonesia (dependent variable). Indicators of social demographic factor include age, sex, education, marital status, religion, occupation, safety assurance, social relation and housing ownership, while indicator of individual decision to migrate from Timor Leste to Indonesia includes migration choice after judging cost benefit related to such social demographic factors.

This research was conducted in West Timor (Indonesia) especially Kupang City, Kupang District and Belu District which are destination regions of migration from Timor Leste. Main border gate where people come in and out such as Mota'ain in Belu District was also observed. Research subjects are migrant population, immigration officials and security apparatus. All selected research subjects become participants whom were given questionnaires about social demographic factor and individual decision to migrate to be filled up. Questionnaires consist of open and closed, 
dichotomy, multiple choice and multiple stage using Likert Scale. Questionnaires were reviewed critically by professionals including lecturer staff from university and relevant non-governmental organizations which handle migrant to evaluate their reliabilities. When the reliability of the questionnaires had been agreed, then pretest was conducted with migrant population in small number to test their content validity, application ease and relevance. Moreover, similar questionnaires were retested their level of reliability with former participants two weeks after. Result of pretest and retest to individual migrants were compared using coefficient Pearson and Spearman correlation. Questionnaires were examined their consistency between the second time retest and the first time pretest. Then, final questionnaires were given to selected research subjects to be filled up. Research subjects amounted to 165 people were determined by using purposive sampling technique.

This research uses two kinds of data sources including : (1) data from published documents, research reports, Indonesian and Timor Leste government reports regarding cross-border migration from Timor Leste to Indonesia; and (2) data from questionnaires which were distributed to all selected research subjects to be filled up. Data collected from questionnaires were coded, edited and processed by using SPSS to obtain their distribution frequency, and present data in table format, and analyze statistically descriptive. This research also used correlation and simple linear regression analysis technique to measure or test the correlation and the influence of independent variable (social demographic factors) to dependent variable (individual decision of Timor Leste people to migrate to Indonesia). Linear regression with one predictor variable (independent variable) uses regression equation format :

$$
\begin{aligned}
& \hat{Y}=\mathrm{a}+\mathrm{bX} \\
& \mathrm{a}=\text { constant or } \mathrm{Y} \text { intercept } \\
& \mathrm{b}=\text { regression coefficient or slope } \\
& \hat{Y}=\text { predicted value of } \mathrm{Y} \text {, dependent variable } \\
& \text { (individual decision to migrate) }
\end{aligned}
$$

$\mathrm{X}=$ independent variable (predictor) (social demographic factor)

\section{RESULT AND DISCUSSION}

\section{A. Descriptive analysis of social demographic factor}

Timor Leste citizens who migrate to Indonesia especially in Kupang City, Kupang District and Belu District have various social demographic characteristics in terms of age, sex, marital status, religion, education, occupation, residency and social relation with population in destination region. Table 1 presents descriptively proportion of each social demographic characteristic of Timor Leste migrants in Kupang City, Kupang District and Belu District with total number of sample are 165.
Table 1

Social demographic characteristics of identified Timor Leste migrants in Kupang City, Kupang District and Belu District

\begin{tabular}{|c|l|r|r|}
\hline No & \multicolumn{1}{|c|}{ Category } & Frequency & Percent (\%) \\
\hline \multirow{4}{*}{1} & Age & 12 & \multicolumn{2}{|c|}{} \\
\cline { 2 - 4 } & $\leq 20$ & 48 & 29.1 \\
\cline { 2 - 4 } & $21-30$ & 43 & 26.1 \\
\cline { 2 - 4 } & $31-40$ & 35 & 21.2 \\
\cline { 2 - 4 } & $41-50$ & 20 & 12.1 \\
\cline { 2 - 4 } & $51-60$ & 7 & 4.3 \\
\cline { 2 - 4 } & $\geq 61$ & 7 & \\
\hline \multirow{2}{*}{2.} & & & \\
\end{tabular}

\begin{tabular}{|l|l|r|r|}
\hline \multirow{2}{*}{2.} & Gender/sex & \multicolumn{3}{|c|}{} \\
\cline { 2 - 4 } & Male & 89 & 53.9 \\
\cline { 2 - 4 } & Female & 76 & 46.1 \\
\hline \multirow{2}{*}{3.}
\end{tabular}

3. Marital status

\begin{tabular}{|l|r|r|}
\hline Married & 108 & 65.5 \\
\hline Un-married & 47 & 28.5 \\
\hline Widower & 2 & 1.2 \\
\hline Widow & 8 & 4.8 \\
\hline
\end{tabular}

4. Religion

\begin{tabular}{|l|r|r|}
\hline Islam & 1 & 0.6 \\
\hline Protestant & 6 & 3.6 \\
\hline Catholic & 157 & 95.2 \\
\hline Hindu & 1 & 0.6 \\
\hline
\end{tabular}

5. Education

\begin{tabular}{|l|r|r|}
\hline Primary School & 46 & 27.9 \\
\hline Secondary School & 28 & 17 \\
\hline Upper Secondary School & 70 & 42.4 \\
\hline $\begin{array}{l}\text { Diploma/Bachelor } \\
\text { Degree }\end{array}$ & 15 & 9.1 \\
\hline Master Degree & 6 & 3.6 \\
\hline
\end{tabular}

6. Occupation

\begin{tabular}{|l|r|r|}
\hline Private official & 21 & 12.7 \\
\hline Government official & 12 & 7.3 \\
\hline Businessman & 90 & 54.5 \\
\hline Student & 36 & 21.8 \\
\hline Un-employed & 7 & 4.3 \\
\hline
\end{tabular}

7. $\quad$ Residential status in destination region

\begin{tabular}{|l|r|r|}
\hline Own house & 84 & 50.9 \\
\hline Family own house & 47 & 28.5 \\
\hline Contract/in the costs & 26 & 15.8 \\
\hline Government/private own & 8 & 4.8 \\
\hline
\end{tabular}

8. Social relation in destination region

\begin{tabular}{|l|r|r|}
\hline Not good/less & 9 & 5.5 \\
\hline Good & 99 & 60 \\
\hline Very good & 57 & 34.5 \\
\hline
\end{tabular}

Table 1 shows that Timor Leste citizens who migrate to Indonesia consist of all age ranging from adolescent, adult and older. However, age group between 21 and 50 is the highest percentage compared to age group $\leq 20$ and $\geq 51$. In terms of sex, migrant male reaches $53.9 \%$ higher than migrant female $(46.1 \%)$, however the percentage number is not so different. This means that the right and freedom of male and female from Timor Leste to migrate to Indonesia are not limited. Aspect of marital status also shows attractive data because Timor Leste married migrants reach the highest 
percentage $(65.5 \%)$ followed by un-married $(28 \%)$ and the smallest percentage is widower $(4.8 \%)$ and widow $(1.2 \%)$. It can be assumed that the percentage number of Timor Leste married migrants correlates positively to the age of migrants because the biggest number of Timor Leste migrants are $\geq 21$ years old. Moreover, Timor Leste migrant whose religion is Catholic Rome (95.2\%) is not so amazing because Timor Leste is the former colonization of Portuguese whose population religion is also Catholic Rome. However, there remains small number of population whose religion is Protestant (3.6\%), Muslim (0.6) and Hindu (0.6). This means that Timor Leste government guarantees the right and freedom of religion in Timor Leste.

Tabel 1 also shows that in terms of eduaction, the highest percentage of Timor Leste migrants are those who were graduated from upper secondary school (42.4\%), followed by primary school $(27.9 \%)$, secondary school $(17 \%)$, diploma/bachelor $(9.1 \%)$ and master degree $(3.6 \%)$. Data in table 1 also show that $54.5 \%$ Timor Leste migrants are businessmen, followed by student $(21.8 \%)$, private official $(12.7 \%)$ and the rest are government official and others. Kupang City, Kupang District, North Middle Timor District and Belu District are regions where the diversity of basic goods are available so that Timor Leste people come to purchase them. These regions also offer several educational institutions that can be entered by Timor Leste students. Moreover, data in table 1 indicate that Timor Leste migrants live in their own house in above mentioned district $(50.9 \%)$, in relatives house $(28.5 \%)$, contract/cost $(15.8 \%)$, and government/private house $(4.8 \%)$. Intention to live permanently in Indonesia determines the ownership status of residency. On the other hand, Timor Leste migrants who choose to live temporarily in Indonesia tend to live in their relative house or contract/cost. Social relation of Timor Leste migrants and local population in Indonesia is not only good $(60 \%)$, but also very good $(34.5 \%)$. Such social relation is generally supported by factors such as strong family ties, similarities in social and cultural values and custom, and high social adaptation and acceptance.

\section{B. Correlation analysis of social demographic factor and individual decision to cross border migration.}

Correlation analysis of social demographic factor (independent variable) and individual decision to cross border migration from Timor Leste to Indonesia (dependent variable) explains the closeness, direction and significance of relationship between these variables. Correlation analysis of independent variable and dependent variable is presented in table 2 below.

Output result of correlation test product moment (Pearson Correlation) in table 2 shows that co-efficient correlation between social demographic factor and individual decision to cross border migration from Timor Leste to Indonesia is 0.003 . This number indicates weak correlation between social demographic factor and individual decision to cross border migration $(<0.05)$. Positive sign indicates that the correlation is in the same direction which means that the higher social demographic factor, the higher individual decision to cross border migration from Timor Leste to Indonesia, and reversely, the lower social demographic factor, the lower individual decision to cross border migration from Timor Leste to Indonesia. Moreover, output correlation analysis indicates that correlation significance between social demographic factor and individual decision to cross border migration is 0.967 . Because this output correlation number indicates that correlation significance is bigger than 0.005 , zero hypotheses (Ho) is accepted. This means that there is no correlation between social demographic factor and individual decision to migrate across the border line from Timor Leste to Indonesia.

Table 2 Correlation analysis of social demographic factor and individual decision to cross border migration between Timor Leste and Indonesia

\begin{tabular}{|l|c|r|r|}
\hline \multicolumn{2}{|c|}{} & \multicolumn{1}{|c|}{$\begin{array}{l}\text { Social demo- } \\
\text { graphic } \\
\text { factor }\end{array}$} & $\begin{array}{c}\text { Individual } \\
\text { decision to } \\
\text { cross border } \\
\text { migration }\end{array}$ \\
\hline $\begin{array}{l}\text { Social demo- } \\
\text { graphic factor }\end{array}$ & Sig. (2-tailed) & 1 & .003 \\
\hline $\begin{array}{l}\text { Individual } \\
\text { decision to } \\
\text { cross border } \\
\text { migration }\end{array}$ & Sig. (2-tailed) & 165 & .967 \\
\hline
\end{tabular}

\section{Regression analysis of social demographic factor on individual decision to cross border migration}

Regression analysis in this research explains the influence of social demographic factor (indipendent variable) on individual decision to cross border migration from Timor Leste to Indonesia (dependent variable) and to explain how the pattern of dependent variable (criteria) can be predicted by the change of independent variable (predictor). Result of simple linear regression analysis is presented in table 3, 4, 5 and 6.

Table 3. Variables Entered/Removed ${ }^{\mathrm{b}}$ of social demographic factor and individual decision to cross border migration between Timor Leste and Indonesia

\begin{tabular}{|c|c|c|c|}
\hline Model & Variables Entered & $\begin{array}{c}\text { Variables } \\
\text { Removed }\end{array}$ & Method \\
\hline 1 & Social demographic factor $^{\mathrm{a}}$ & & Enter \\
\hline
\end{tabular}

a. All requested variables entered.

b. Dependent Variable: Individual decision to cross border migration

Table 4. Model summary of social demographic factor and individual decision to cross border migration between Timor Leste and Indonesia

\begin{tabular}{|c|c|r|r|r|}
\hline Model & $\mathrm{R}$ & R Square & \multicolumn{1}{c|}{$\begin{array}{c}\text { Adjusted R } \\
\text { Square }\end{array}$} & $\begin{array}{c}\text { Std. Error of the } \\
\text { Estimate }\end{array}$ \\
\hline 1 & $.003^{\mathrm{a}}$ & .000 & -.006 & 2.961 \\
\hline
\end{tabular}

a. Predictors: (Constant), Social demographic factor 
Table 5. ANOVA ${ }^{\mathrm{b}}$ of social demographic factor and individual decision to cross border migration between Timor Leste and Indonesia

\begin{tabular}{|c|c|r|r|r|r|l|}
\hline \multicolumn{2}{|c|}{ Model } & $\begin{array}{c}\text { Sum of } \\
\text { Squares }\end{array}$ & \multicolumn{1}{c|}{ df } & $\begin{array}{c}\text { Mean } \\
\text { Square }\end{array}$ & F & Sig. \\
\hline \multirow{2}{*}{1} & Regression & 15.879 & 1 & 15.879 & .964 & $.328^{\mathrm{a}}$ \\
\cline { 2 - 8 } & Residual & 2685.915 & 163 & 16.478 & & \\
\cline { 2 - 8 } & Total & 2701.794 & 164 & & & \\
\hline
\end{tabular}

a. Predictors: (Constant), Social Demographic Factor

b. Dependent Variable: Individual decision to cross border migration

Table 6. Coefficients ${ }^{\mathrm{a}}$ of social demographic factor and individual decision to cross border migration between Timor Leste and Indonesia

\begin{tabular}{|c|c|c|c|c|c|c|}
\hline \multirow{2}{*}{\multicolumn{2}{|c|}{ Model }} & \multicolumn{2}{|c|}{$\begin{array}{l}\text { Unstandardized } \\
\text { Coefficients }\end{array}$} & \multirow{2}{*}{$\begin{array}{c}\begin{array}{c}\text { Standardized } \\
\text { Coefficients }\end{array} \\
\text { Beta } \\
\end{array}$} & \multirow[b]{2}{*}{$\mathrm{t}$} & \multirow[b]{2}{*}{ Sig. } \\
\hline & & B & $\begin{array}{l}\text { Std. } \\
\text { Error }\end{array}$ & & & \\
\hline \multirow[t]{2}{*}{1} & (Constant) & $\begin{array}{r}23 . \\
281\end{array}$ & 1.280 & & $\begin{array}{r}18 . \\
194\end{array}$ & .000 \\
\hline & $\begin{array}{l}\text { Social demo- } \\
\text { graphic factor }\end{array}$ & .003 & .073 & .003 & .042 & .967 \\
\hline
\end{tabular}

a. Dependent Variable: individual decision to cross border migration

From coefficent output table, simple linear regression analysis of social demographic factor on individual decision to cross border migration from Timor Leste to Indonesia can be done by using equation format of simple linear regression analysis :

$$
\begin{aligned}
& Y ́=a+b X \\
& \text { Where, }
\end{aligned}
$$

$\hat{Y}=$ predicted value of $\mathrm{Y}$, dependent variable (individual decision to migrate)

$\mathrm{a}=$ constant or $\mathrm{Y}$ intercept, $\mathrm{b}=$ regression coefficient or slope, and $\mathrm{X}=$ independent variable (predictor) (social demographic factor). If simple regression coefficient value that exist on coefficient output table is entered into simple linear regression equation format, the result is :

$\mathrm{Y}=23.281+0.003 \mathrm{X}$

Where,

The constant is 23.281 indicates that if social demographic factor is zero, individual decision to cross border migration is 23.281. Coefficient $b=0.003$ indicates that if social demographic factor increases one unit, individual decision to cross border migration from Timor Leste to Indonesia will increase 0.003 unit.

From output table of Model Summary, it can be known that $\mathrm{R}^{2}$ ( $\mathrm{R}$ Square) value is 0.000 . This means that social demographic factors have no influence on individual decision to cross border migration from Timor Leste to Indonesia. $\mathrm{T}$ test to examine the significance of constant and independent variable can be formulated by hypotheses :

$$
\begin{array}{ll}
\mathrm{H}_{\mathrm{o}}: \mathrm{b}=0, & \begin{array}{l}
\text { Means that social demographic factor have no } \\
\text { influence on individual decision to cross border } \\
\text { migration from Timor Leste to Indonesia }
\end{array}
\end{array}
$$

$\mathrm{H}_{\mathrm{a}}: \mathrm{b} \neq 0$, Means that social demographic factor have an influence on individual decision to cross border migration from Timor Leste to Indonesia
Significance level used in this research is 0.05 . From output data on coefficient table, calculation of $t$ count is 0.042 . Furthermore, $\mathrm{t}$ table can be found from statistic table in 0.05 significance with df $=\mathrm{n}-2$ or $165-2=163$. With two sides test, it can be obtained t table 1.975. From calculation result of $\mathrm{t}$ count and $\mathrm{t}$ table, it is known that $\mathrm{t}$ count $(0.042)<\mathrm{t}$ table (1.975), so zero hypotheses is accepted. The conclusion is that social demographic factor has no influence on individual decision to cross border migration from Timor Leste to Indonesia, however, its influence is positive because coefficient and t count is positive, which means that if social demographic factor increases, individual decision to cross border migration from Timor Leste to Indonesia also increases.

Social demographic factors include age, sex, religion, occupation, education, marital status, residential ownership and social relation. The result of statistical analysis indicates that indicators of social demographic factor mentioned above are not the main judgement or reason of Timor Leste citizen to migrate across the border line to Indonesia.

Different from this research result, research conducted by Martinez (2014) on "Beyond networks : health, crime and migration in Mexico" found that individual characteristics such as young age, male, marital status and high education have positive correlation with decision to migrate. However, individual who owns his/her own house have low tendency to migrate. Neo-clasic approach also describes that social, economic and demographic characteristics of individual and his/her family that is related to income earning in destination region becomes cost-benefit judgement which determine individual decision and his/her family to migrate. Neo-clasic approach correlates closely to job market, where individual migrates to obtain job and income in destination region.

Of course neo-clasic approach is different from migration phenomenon between Timor Leste and Indonesia where not because of cost-benefit calculation in terms of job procurement and income earning in destination region, but decision to migrate across the border line from Timor Leste to Indonesia is mainly determined by geographical closeness, family visit, study continuation and trade of basic goods. Geographical closeness where Timor Leste and West Timor (Indonesia) is in similar island provides very easy access, efficiency and effectiveness of cross border migration. Social and cultural similarities from both sides, and close family ties also determine decision quality to migrate across the border line from Timor Leste to Indonesia. Based on these factors, cross border migration from Timor Leste to Indonesia is not because of neo-clasical perspective which emphasizing economic benefit, but on social cultural benefits and close family ties. Adequate availability of educational institutions and goods in Indonesia also becomes a specific attraction for some people from Timor Leste to migrate to Indonesia aiming to continuing study and trade. 


\section{CONCLUSION}

Statistical descriptive in this research explains that the highest percentage of Timor Leste people who migrate to Indonesia is at the age of $\leq 50$ years old, Catholic, married, primary school and upper secondary school, businessmen, having their own house, and good social relation, while in terms of sex, the percentage of male and female is nearly similar. Correlation and simple linear regression analysis in this research also explains that social demographic factors have no correlation and influence on individual decision to migrate across the border line from Timor Leste to Indonesia. It is assumed that cross border migration from Timor Leste to Indonesia especially West Timor mainly correlates with and is influenced by geographical closeness, family visit, study continuation and trade. Government and all stakeholders need to pay attention and provide equal services based on the diversity of social demographic characteristics, the need of Timor Leste people, and the main causes of cross border migration from Timor Leste to Indonesia so that every migrant can experience equity in services and satisfaction. Further research is necessary to examine another influential factors on individual decision to cross border migration from Timor Leste to Indonesia by using both quantitative and qualitative approach or mixed method.

\section{References}

[1] Anb, D. N. 2003. Cross border migration and sexuality in Vietnam : reality and policy responses. In Darwin, M., Wattie, A. M., \& Yuarsi, S. E. (Eds), Living on the edges: cross border mobility and sexual exploitation in the Greater Southeast Asia Region. (pp. 47-96). Yogyakarta : Center for Population and Policy Studies Gadjah Mada University.

[2] Darwin, M., Wattie, A. M., \& Yuarsi, S. E. (Eds). 2003. Living on the edges: cross border mobility and sexual exploitation in the Greater Southeast Asia Region. Yogyakarta : Center for Population and Policy Studies Gadjah Mada University.

[3] Darwin, M., Wattie, A. M., Dzubayatin, S. R., \& Yuarsi, S. E. 2003. Trafficking and sexuality in Indonesia-Malaysia cross border migration. In Darwin, M., Wattie, A. M. \& Yuarsi, S. E. (Eds), Living on the edges: cross border mobility and sexual exploitation in the Greater Southeast Asia Region. (pp. 233-282). Yogyakarta : Center for Population and Policy Studies Gadjah Mada University.

[4] Dye, T. R. 2002. Understanding public policy. New Jersey : Prentice Hall.

[5] Kraft, M. E., \& Furlong, S. R. 2007. Public policy : politics, analysis and alternatives (2nd ed.). Washington, D.C : CO Press.

[6] Loether, H. J., \& McTavish, D. D. 1993. Descriptive and inferential statistics : an introduction, fourth edition. Boston : Allyn and Bacon.

[7] Martinez, J. N. 2014. Beyond Networks: Health, Crime, and Migration in Mexico.International Journal of Population Research, Vol 2014. Article ID 971739, 12 pages http://dx.doi.org/10.1155/2014/971739

[8] Meijers, E., \& Stead, D. 2004. Policy integration: what does it mean and how can it be achieved? A multi-disciplinary review. Delft University of Technology OTB Research Institute for Housing, Urban and Mobility Studies, The Netherlands

[9] Pal, L. A. 2006. Beyond Policy Analysis : Public Issue Management in Turbulence Time (3rd Ed.). Canada: Thomson Nelson.

[10] Pimpawun, B., Guest, P., Marddent, A., \& Sander, S. 2003. From trafficking to sex work: Burmese migrants in Thailand. In Darwin, M., Wattie, A. M., \& Yuarsi, S. E. (Eds), Living on the edges: cross border mobility and sexual exploitation in the Greater Southeast Asia Region. (pp. 163-230). Yogyakarta : Center for Population and Policy Studies Gadjah Mada University.
[11] Phillips, R., Head, B., \& Jones, A. 2012. Integrated responses to homelessness in Australia: an analysis of 'joined up' policy and practice. Australia : Institute for Social Science Research, The University of Queensland.

[12] Saikia, U. \& Hosgelen, M. 2010. Timor Leste's demographic destiny and its implications for the health sector by 2020 . Journal of Population Research, 27 (2): 133-146.

[13] Santos, A. F., \& Munez, M. P. 2003. Emergent sexuality issues among selected population of Filipino migrants. In Darwin, M., Wattie, A. M., \& Yuarsi, S. E. (Eds), Living on the edges: cross border mobility and sexual exploitation in the Greater Southeast Asia Region. (pp. 285-320). Yogyakarta : Center for Population and Policy Studies Gadjah Mada University.

[14] Skeldon, Ronald. 2000. Populaztion Mobility and HIV Vulnerability in South East Asia : An Assessment and Analysis. United Nation Development Programme (UNDP) South East Asia HIV and Development Project, Thailand. (Based on a presentation given an the UNDP South East Asia HIV and Development Project workshop on Population Movement and HI Vulnerability Chiang Rai, Thailand 10-12 November 1999).

[15] Sugiyono. 2013. Metode penelitian kombinasi (mixed methods). Bandung : Penerbit Alfabeta.

[16] Supardi, U.S. 2012. Aplikasi statistika dalam penelitian : buku statistika yang paling komprehensif. Jakarta : Ufuk Press.

[17] Tran, U. N. T. L. 2012. Vietnamese Immigrants in Brisbane, Australia: Perception of Parenting Roles, Child Development, Child Health, Illness, and Disability, and Health Service Utilisation. International Journal of Population Research, Vol 2012., Article ID 932364, 12 pages. doi:10.1155/2012/932364

[18] UN Information Service. 19 March 2003. Convention on Protection of Rights of Migrants. Geneva, Switzerland.

[19] Wilson, F. A., Stimpson, J. P., \& Pagán, J. A. 2014. Disparities in Health Outcomes of Return Migrants in Mexico. International Journal of Population Research, Vol 2014., Article ID 468250, 9 pages. http://dx.doi.org/10.1155/2014/468250

[20] Zbixiong, H. 2003. Cross border migration and sexuality in Vietnam : reality and policy responses. In Darwin, M., Wattie, A. M. \& Yuarsi, S. E. (Eds), Living on the edges: cross border mobility and sexual exploitation in the Greater Southeast Asia Region. (pp. 3-44). Yogyakarta : Center for Population and Policy Studies Gadjah Mada University. 